Oleg Yarosh

\title{
Sufi Communities in the West: Charisma and Institutionalization
}

This paper examines the institutional development of transnational Sufi communities in the West. Western Sufism has been developing in a social-cultural milieu that is marked by the "specialization of institutional domains, the pluralism of mass-culture, and the development of a market of world views" . Privatization of religion as a new social form is driven by the development of the private sphere, individual autonomy and liberal values, as a result "the individual is given the freedom to choose from a variety of sacred universes" 2 . Thomas Luckmann describes this privatized social form of religion as "relying primarily on an open market of diffuse, syncretistic packages of meaning, typically connected to low levels of transcendence and produced in a partly or fully commercialized cultic milieu"'3. This idea is echoed by Danièle HervieuLéger who claims that "religious modernity" is characterized by plurality of individual religious combinations, and weakening of the institutionalized belief systems; in other words, it is driven by individualized dispersion and the decay of religious codes that maintained collective religious identities ${ }^{4}$.

Historically, transnational Sufi cults mediated connections between the different parts of the Islamicate World and they were also critical in spreading Islam beyond its borders not only as a source of religious practice and knowledge, but also as a civil and political force. Nile Green presents a very fitting description for these trans-regional Sufi cults as "cultural technology of inter-

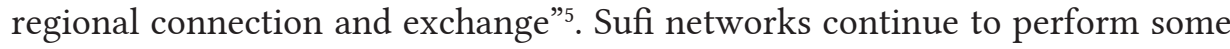
of these functions today in the Muslim diasporas located in the West, maintaining for example "complex relationships with homeland societies while simultaneously developing global contacts crossing the ethnical links and thereby becoming the channels of the cultural flows".

${ }^{1}$ T. Luckmann, The Religious Situation in Europe: The Background to Contemporary Conversions, "Social Compass" 1999, Vol. 46, Issue 3, pp. 251-258.

${ }^{2}$ Idem, The privatization of religion and morality, [in:] Detraditionalization: Critical Reflections on Authority and Identity, eds P. Heelas, S. Lash, P. Morris, Cambridge, Mass. 1996, p. 73.

${ }^{3}$ Ibidem, p. 73.

${ }^{4}$ D. Hervieu-Léger, In search of certainties: the paradoxes of religiosity in societies of high modernity, "The Hedgehog Review" 2006, Vol. 8, No. 1-2, p. 60.

${ }^{5}$ N. Green, Sufism: A Global History, Chichester-Malden, MA 2012, pp. 12, 44.

${ }^{6}$ C. Raudvere, L. Stenberg, Translocal mobility and traditional authority, [in:] Sufism Today: Heritage and Tradition in the Global Community, eds C. Raudvere, L. Steinberg, London-New York 2009, p. 5. 
The spread of Sufism in particular Western countries has its own distinctiveness, due to their history and socio-cultural factors. Obviously, the colonial empires, first of all, Great Britain, have better preconditions for the emergence and spread of Sufi communities than the other countries. The process of revival of Sufism in regions with a significant Muslim population and who have previously been influenced by the policy of forced secularization, in particular in Central Asia, the North Caucasus, the Volga region, also has its own peculiarities. Here, often, the development of transnational Sufi movements is combined with a revival of local institutions and traditions, which sometimes leads to conflicts, especially in those regions where traditional Sufism retained a certain presence during the Soviet times.

The peak of interest in the development of Sufism in the West came at the end of the 2000s, when a number of works devoted to this subject were published ${ }^{7}$. Among the recent studies, we should mention the comprehensive work of Mark Sedgwick "Western Sufism: from the Abbasids to the New Age", where, among other things, the author raises the problems of determining the terminological framework and periodization of "Western Sufism". In turn, the well-known scholar of Western esotericism Wouter J. Hanegraaf points out that Judaism and Islam should be viewed as an integral part of the history of religions in Europe, so it is natural to include esoteric traditions in these religions in the area called "Western esotericism".

Sedgwick regards the Western Sufi movements as "neo-Sufi", i.e. more as a part of the landscape of Western esotericism than Islam. Further classification of "neo-Suf" movements includes Islamic Sufism, non-Islamic Sufism, and partly Islamic Sufism ${ }^{10}$. The first category includes groups that have emerged among migrants from Muslim countries who have lost ethnic homogeneity in a later period, but nevertheless retain a visible connection to Islam; the second category includes those who consider Sufism apart from Islam as the universal "Truth", for example, the followers of Hazrat Inayat Khan (1882-1927); finally, the third group includes those who retain a certain connection to Islam, for example, Maryamiyya. Thus, this classification is based on attitudes towards the normative tradition of Islam.

In his latest work, mentioned earlier, Sedgwick uses the term "Western Sufism" as a synonym for "neo-Sufism". In general, he views Western Sufism as

${ }^{7}$ See: Sufism in the West, eds J. Malik, J. Hinnells, London-New York 2006; Sufis in Western society: global networking and locality, eds R. Geaves, M. Dressler, G. Klinkhammer, LondonNew York 2009; Sufism Today: Heritage and Tradition...

${ }^{8}$ M. Sedgwick, Western Sufism: from the Abbasids to the new age, New York 2017.

${ }^{9}$ W.J. Hanegraaff, Western esotericism: a guide for the perplexed, London-New York 2013, p. 15.

${ }^{10}$ M. Sedgwick, Neo-Sufis, [in:] Dictionary of Gnosis and Western Esotericism, ed. W.J. Hanegraaff, Leiden-Boston 2006, p. 846. 
a product of Islam, the ancient world, and western intellectual history from the Renaissance through Spinoza to Helena Blavatsky and Doris Lessing ${ }^{11}$.

Marcia Hermansen offers several options for the typology of Western Sufi movements. The most famous of them is as follows ${ }^{12}$ :

"Perennials": consider Sufism to be a universal mystical tradition outside the context of Islam or rethink it in the context of the ideas of traditionalism (Rene Guenon and others);

"Hybrids": they have a greater connection with the Islamic tradition; however, they appropriate it to the Western European socio-cultural context and have many followers from among Europeans;

"Transplants": formed mainly by Muslim disaporas, reproduce the sociocultural patterns and religious traditions of their countries of origin;

The basis of this typology is also the attitude towards the Islamic normative tradition and practice. At the same time, this typology also takes into account the ethnic composition of the Sufi communities in the West and allows conclusions to be drawn about its influence on discourse and practices in particular communities.

In the other paper ${ }^{13}$ Hermansen proposes the following typology of global Sufi cults: "theirs", which originated and are based in Muslim societies and are spread through missionary activities and migrations, and "ours", whose center is located in Western countries. Among the latter, she identifies the following categories: eclectic Sufi movements; communities led by Sheikhs of Western origin; communities headed by a Sheikh from Muslim country. In my opinion, this classification is somewhat less fitting than the previous one, since its criteria appear rather vague, because of a number of "eclectic" Sufi communities headed by Sheikhs from Muslim countries. Moreover, since global Sufi cults have a network structure, local communities operate largely autonomously and their attitude to the Islamic tradition may differ significantly from the official discourse.

Hermansen puts forward yet another approach to the typology of Western Sufism, based on the attitude towards the normative tradition of Islam and the institutional aspects of Sufi communities ${ }^{14}$. She identifies "universal Sufism", combining elements of Sufi and Islamic traditions, while not requiring of the followers a formal conversion to Islam and the observance of religious precepts. The Sufi organizations based on the Inayat Khan teachings, such

\footnotetext{
${ }^{11}$ M. Sedgwick, op. cit., p. 2.

${ }^{12} \mathrm{M}$. Hermansen, In the Garden of American Sufi Movements: Hybrids and Perennials, [in:] New Trends and Developments in the World of Islam, ed. P.B. Clarke, London 1998, pp. 155-158.

${ }^{13}$ Idem, Global Sufism: "Theirs and ours", [in:] Sufis in Western society..., p. 33.

${ }^{14}$ Idem, Sufi movements in America, [in:] The Oxford Handbook of American Islam, eds Y.Y. Haddad, J.I. Smith, Oxford 2014, pp. 122-123.
} 
as the "International Sufi Order" and other groups, are given as an example. The next category is "Islamic Sufi movements", which, in general, are based on the normative Islamic tradition, at the same time; particular communities may be more eclectic in their views and practices. Among the Islamic movements, Hermansen identifies a special category that is called "post-tariqa movements", for example, "Tablighi Jama'at", the movement "Nurcu" by Said Nursi (18781960) and "Hizmet" by Fethullah Gulen (b. 1942). A distinctive feature of such movements is that there is no initiation (bay'a) as well as a formal continuity (silsila) with other Sufi brotherhoods, that is, they are not considered to be their continuation or branch.

Other typologies based on the attitude of Sufi movements to the normative Islamic tradition include the concept of Allan Goddas, who distinguishes between "Islamic", "quasi-Islamic", "non-Islamic" and "related to Sufism" movements ${ }^{15}$. At the same time, this approach suffers from over-generalization and does not take into account the peculiarities of the attitudes towards the Islamic normative tradition in various local communities belonging to the global Sufi cults ${ }^{16}$.

A qualitatively different approach to typology is offered by Markus Dressler, who classifies the Western Sufi communities according to their attitude to the host society and its sociocultural norms ${ }^{17}$. He identifies the following attitudes: criticism of Western society and its norms, and closure in itself; acceptance of norms and active participation in public life while maintaining their own separate identity; and fusion of Western and Muslim identity. However, the disadvantage of this typology is that it does not take into account the attitude of these groups to the religious tradition.

In turn, Søren Lassen, offers a typology based on the ethnic and social composition of the communities: "diasporic", uniting mainly migrants; consisting of converts; and, finally, "New Age-related Sufi groups"18. This typology is also insufficient, since a significant part of the Sufi community unites both ethnic Muslims and converts and those who formally did not convert to Islam.

In my opinion, Hermansen's first typology seems to be the most heuristically valuable and properly describes a significant part of Sufi communities in the West. At the same time, these categories should be considered as "ideal types", in the Weberian sense, as models of a social phenomenon, summarizing its characteristic features, and which cannot be found in their pure form in reality.

${ }^{15}$ A. Goddas, Sufism's Many Paths, http://www.uga.edu/islam/Sufism.html, retrieved 2.01.2019.

${ }^{16} \mathrm{O}$. Yarosh, Western Sufi communities between hybridity and authenticity. The Sufi Centre Rabbaniyya in Berlin, "Pantheon" 2015, Vol. 10, No. 2, p. 16.

${ }^{17}$ M. Dressler, Pluralism and authenticity: Sufi paths in post-9/11 New York, [in:] Sufis in Western society..., pp. 80-81.

${ }^{18}$ S.Ch. Lassen, Growing up as a Sufi: generational change in the Burhaniya Sufi order, [in:] Sufis in Western society..., p. 148. 
Let us turn to the consideration of the periodization of the development of Sufism in the West. Some researchers distinguish between three stages, sometimes calling them "waves".

Thus, the American researcher Gisla Webb describes these "waves" in the context of the development of Sufism in America as follows ${ }^{19}$ :

"Sufism of the first wave" at the beginning of the 20th century, characterized by the interest of Americans and Europeans in "Eastern wisdom", the emergence of "Eastern teachers", such as Inayat Khan, which gave Sufism a universalistic and theosophical character;

"Sufism of the second wave" in the 60s-70s of the 20th century is also associated with the development of mystical universalism and traditionalism, as well as the emergence of the first Sufi orders from Muslim countries;

"Sufism of the third wave", starting from the 90s, is characterized by globalization, the increase in Muslim diasporic communities and the growth of their self-awareness, the intensification of public activities of Sufi communities, which manifests itself in the social sphere and interfaith dialogue.

Gritt Klinkhammer also considers the three stages of the development of Sufism in the West (in the context of Germany), although she characterizes them somewhat differently than Webb. The first stage is connected with "perrenalism", the search for an eternal, universal "Truth"; the second stage is characterized by the influence of "New Age" and, finally, the third, is associated with the formation of German branches of Sufi orders such as Naqshbandiyya, Burkhaniyya and Mevleviyya. Klinkhammer regards the last stage as a "turn to authenticity" when followers and communities reject syncretism and eclecticism previously shared by them and embrace more "authentic" forms of "Sufi life", imitating Sufism that is traditional for their Sheikh's homeland ${ }^{20}$.

In turn, Sedgwick identifies four main stages of reception and dissemination of Sufism in the West: in the first stage, in the Middle Ages, Sufism influenced Jewish mysticism and indirectly the mystical tradition of Western Christianity; in the second stage, in the early modern period, acquaintance with Sufism takes place through texts, which, in turn, affects the understanding of religion in the West; at the third, modern stage, the first Sufi groups appeared in the West; in the fourth, also modern, stage, these groups developed in different ways. The second part of the fourth stage, which is the current period, is characterized as "post-New Age" 21.

${ }^{19} \mathrm{G}$. Webb, Third-wave Sufism in America and the Bawa Muhaiyaddeen Fellowship, [in:] Sufism in the West, eds J. Malik, J. Hinnells, London-New York 2006, pp. 87-91.

${ }^{20} \mathrm{G}$. Klinkhammer, The emergence of transethnic Sufism in Germany. From mysticism to authenticity, [in:] Sufis in Western society..., pp. 142-143.

${ }^{21}$ M. Sedgwick, Western Sufism..., p. 6. 
The institutional structure of Sufi communities encompasses initiative hierarchies of dominance and collective solidarity regarded by Pnina Werbner as "redemptive sociality" based on bonds with a charismatic Sufi Sheikh"2 The charismatic bond is delivered from the followers' recognition of Sheikh's "supernatural powers", experienced as intense emotional attraction, and preformed through rituals, practices and narratives.

A remarkable feature of Western Sufism is the community-building process based on a commune model. These self-sustaining communes, usually located in rural areas, brought together people of diverse beliefs and attitudes, generally following different spiritual trends. The development of religious movements in the West in the 1970s and 1980s as part of a "cultic milieu" (Colin Campbell) was marked by the emergence of religious communes where followers of the spiritual leader lived together in a remote area and also often conducted collective farming. The largest number of such communes belonging to new religious movements arose in the United States.

The practice of creating religious communes did not bypass the Western Sufi movements. Among the western Sufi communes, we should mention the "Abode of the Message" of the "International Sufi Order", founded by Pir Vilayat Khan in 1975 near the town of New Lebanon in New York State on the site previously occupied by the Protestant Shaker community. This community had 150 members in the mid-1980s. Among the other Sufi commune communities, mention should be made of the centers founded by Abdalqadir as-Sufi near Norfolk in the UK (1976) and near the city of Tucson in Arizona (1978). At its peak, the Norfolk community numbered 200 families.

Another notable community, consisting of the followers of the Sheikh Fadhlalla Haeri, arose in 1980 in the county of Blanco, near the city of San Antonio in Texas. In 1981 the Bayt al-Deen complex (the House of Religion) was built here, which included a mosque, a madrasah for western students, and a residential sector. According to the plan of the Sheikh Fadhlalla, Bayt al-Deen was to emulate the community of the first Muslims in Medina. At that time Sheikh Fadhlalla was closely associated with Sheikh Abdalqadir and was his amir (representative) in Blanco. Since 1982 the Sheikh Fadhallah has started independent activities as the leader of the tariqa Haydariyya-Shadhiliyya. After the Sheikh Fadhlalla moved to London in 1985, the community gradually began to decline and in 1996 finally ceased to exist.

Although in Western Europe religious communes did not become as widespread as in North America, some Sufi communes also appeared there. One of the most significant for the popularization of Sufism in Western Europe was the "Haus Schnede" Sufi commune. Gritt Klinkhammer emphasizes that

${ }^{22} \mathrm{P}$. Werbner, Murids of the Saint: Occupational Guilds and Redemptive Sociality, [in:] Muslim Traditions and Modern Techniques of Power, ed. A. Salvatore, Münster 2001, pp. 265-289. 
for the first German followers, whom she calls "religious individualists" and who previously belonged to different currents within the "New Age" movement, Sufism was primarily a universal spiritual psychology and an effective tool for self-development ${ }^{23}$. Many of those who later became Sheiks in the 70's and 80's conducted various seminars based on humanistic and transpersonal psychology in combination with dhikr practices ${ }^{24}$.

The most famous spiritual teachers of the Western Sufi tradition of that time in Germany were Muhammad Salah Id, Abdul Halis Dornbrach and Hussayn Abdul Fattah (Stefan Makovsky), who in 1979 founded the "Institute of Sufi Studies" in Berlin. A year later they moved to the "Haus Schnede" mansion rented by Stefan Makovsky and Salah Id in the Luneburg Heath in Lower Saxony, opened the "School of Sufi Healing" and registered the Sufi community ${ }^{25}$. Salah Id was associated with the Burhaniyya tariqah, and his closest associate, Hussayn Abdul Fattah, with the Naqshbandiyya-Haqqaniyya tariqa of Sheikh Nazim al-Kubrusi. After the death of Salah Id in a car accident in 1981, soon after the opening of the center, Hussayn Abdul Fattah became its leader.

Originally members of the community lived together in "Haus Schnede", which also served as a venue for various Sufi seminars and other events in which prominent Sufi teachers, such as Muzaffer Ozak, Reshad Field, Nazim al-Kubrusi and others participated ${ }^{26}$. Later, members of the community moved to the nearby town of Salzhausen. Among them were followers of the Burhaniyya and Naqshbandiyya-Haqqaniyya, as well as followers of the other religious teachers, in particular Osho ${ }^{27}$.

By the mid 1980s, small autonomous groups began to form within this community focused on one or another leader and practice ${ }^{28}$ that finally led to its partition and decline. Since the second half of the 1980s, NaqshbandiyyaHaqqaniyya has been actively developing in Germany and new centers were opened $^{29}$. In this regard, the significance of "Haus Schnede" for this tariqa was diminishing and the influence of the followers of Burhaniyyah had been increased in this community. Despite his former connection with NaqshbandiyyaHaqqaniya, Hussayn Abdul Fattah also began to side more with Burhaniyya.

Khalid Duran mentions that the followers of the Burikaniyya tariqa were strict about their adherence to Islamic practices and traditions ${ }^{30}$. To a large extent, this was facilitated by the visit of 40 members of the community in late

${ }^{23}$ G. Klinkhammer, op. cit., p. 136.

${ }^{24}$ Ibidem, p. 131.

${ }^{25}$ Ibidem, pp. 137, 145.

${ }^{26}$ S.Ch. Lassen, op. cit., p. 203.

${ }^{27}$ G. Klinkhammer, op. cit., p. 138.

${ }^{28}$ Ibidem, p. 137.

${ }^{29}$ Ibidem, p. 140.

${ }^{30}$ Kh. Duran, Muslim Diaspora: The Sufis in Western Europe, "Islamic Studies” 1991, Vol. 30, No. 4, p. 467. 
1981 to Khartoum, where they met with Sheikh Muhammad Uthman and this event marked the beginning of the history of Burhaniyya in Western Europe ${ }^{31}$.

Because of the fact that part of the "Haus Schnede"community began turning to strict adherence to the Islamic practices and doctrines, a conflict arose between the adherents of the "orthodox" and "universalist" approach to Sufism. Over time, the contradictions between "universalists" and adherents of a more rigorous approach to normative Islam have only intensified.

In 1984 the son and successor of Sheikh Muhammad Uthman Sheikh Ibrahim Muhammad displaced Hussayn Abdul Fattah. For some time he continued to lead a small community of his followers who gathered in Bahlburg ${ }^{32}$. Then he returned to Austria and opened the "Institute of Sufi Studies" in Salzburg. Thus, the "universalist community" in "Haus Schnede" actually ceased to exist.

Sheikh Ibrahim Muhammad sought to create from a heterogeneous community a more formal structure based on the principles of the tariqa, i.e. initiationoath (bay'a) and subordination to the authority of the Sheikh and also following the precepts of Islam. In 1991 the Burhaniyya Foundation was established, and in 1992, "Haus Schnede" became the official center of Burhaniyya ${ }^{33}$.

"Haus Schnede" has played a significant role in the history of Western Sufism, being a kind of "hub" that connected spiritual leaders and their followers from different countries of Europe and initiated the development of Sufi communities in Europe, primarily Burhaniyya and Naqshbandiyya-Haqqaniyya. The activities of the center contributed to the formation of a religious commune that originally unites people who hold different views on the process of spiritual development and the nature of Sufism, as well as diverse religious practices.

In the context of our study, we should also turn to the commune of the followers of the Sheikh Fadhlalla, which existed in the 90's in the vicinity of Gothenburg. In 1991 five Swedish murids of Sheikh Fadhlalla rented a house known as the "Pink House" in the village of Gråbo near Gothenburg and laid the foundation for the Sufi center, which later became known as the "Society of Sophia" ${ }^{34}$. Members of the community lived together, and their number at different times was 20-40, most of whom had previously belonged to different New Age currents. In the mid 90s, Sheikh Fadhlalla visited his followers several times in Sweden, and later transferred the community to his close friend Sheikh Asaf Durakovich of the Balkan branch of Rifa'iyya tariqa. In the late 90s, the community broke up due to internal conflicts. At the same time, some of its members still organize various collective events, in particular, the "Sufi retreat" in the town of Åsa on the Baltic Sea shore near Gothenburg. Further,

${ }^{31}$ S.Ch. Lassen, op. cit., pp. 192-193.

${ }^{32}$ Kh. Duran, op. cit., p. 472.

${ }^{33} \mathrm{G}$. Klinkhammer, op. cit., p. 141.

${ }^{34}$ S. Sorgenfrei, Sufism i Sverige - En lägesrapport från Stockholm, Göteborg och Malmö, Stockholm 2016, p. 59. 
I refer to my interactions with the community members during fieldwork there in October 2016 - January 2017.

N. is one of the closest longtime disciples of Sheikh Fadhlalla and, sometimes on his own initiative, and sometimes at the request of the audience, he often talks about unusual events related to the Sheikh and about the manifestations of his "supernatural powers". These narratives are aimed at inspiring religious emotions and increasing attachment to the Sheikh among his followers.

Among the stories about the "miracles" transmitted by N. there are those that are related to the influence on living beings (communication with a bird) and inanimate nature (the rotation of a plate with calligraphy of "Allah" around the wall); the ability to communicate directly with the Prophet Muhammad; knowledge of the hidden (can observe the student who is thousands of kilometers away). N. also emphasizes the effect of direct communication with Sheikh Fadhlalla. According to him, the printed text does not convey $90 \%$ of the full meaning of what the Sheikh says. Once, when he took notes of the Sheikh's speech on a laptop, after the words "There is no other door but Him", his hands trembled and the laptop fell to the floor. N. also speaks of the effect of automatic writing that he sometimes takes notes after the Sheikh, without realizing what he has just written: "I look at the screen and do not believe that I just wrote it myself”"

Another close associate of Sheikh Fadhlalla emphasizes the interactive nature of charisma, saying that the students are responsible for the Sheikh. According to him, Sheikh Fadhlalla contains plenty of light, but many cannot bear it and leave the Sheikh. They think that there is nothing unusual in the Sheikh, but the problem lies in them. N. also said that the Sheikh, as a perfect mirror, reflects the shortcomings of others, therefore many quit. The motive of spiritual "healing" and "development", often tied to charismatic authority, is also often found in Western Sufi communities. Many of the new converts and those who did not formally embrace Islam are more interested in "personal development technologies" than the doctrinal and ritual aspects of Sufism ${ }^{35}$.

Michael Gilsenan describes the role of the miracle as a legitimization of holiness and transforming power. Miracles in cultural epistemology attach importance to experience, and the saint appears as a certain channel, through which a connection is established between events, previously hidden, which is important to his authority ${ }^{36}$. In this case, miracles are interpreted, codified and regulated within the framework of the dominant discourse ${ }^{37}$. The Sheik's charisma

${ }^{35}$ O. Yarosh, Religious Authority and Conversions in Berlin's Sufi Communities, [in:] Moving in and out of Islam, ed. K. van Nieuwkerk, Austin 2018, p. 187.

${ }^{36}$ M. Gilsenan, Recognizing Islam: Religion and Society in the Modern Middle East, LondonNew York 2000, p. 77.

${ }^{37}$ Ibidem, p. 78. 
also plays a crucial role in the process of conversion. Julianne Hazen, who studied the 'Alami Tariqa in Waterport, New York, points out that commitment to the Sheikh plays an important role in the conversion process, especially for those people converted through the tariqa ${ }^{38}$. In their narratives, members of Sufi communities often express deep affection and respect for their Sheikhs ${ }^{39}$.

This social bounding and bilateral relationship with the Sheikh inside Sufi communities are reinforced through regular religious ceremonies, teaching, and training and shared social activities. Usually relatives of the Sheikh and the most trusted followers are responsible for organizing these events as well as for administrative work and planning trips for the network leadership ${ }^{40}$.

Therefore "redemptive sociality" or collective solidarity based on bonds with a charismatic Sufi Sheikh as a living saint who is able to transmit "supernatural powers" to the community is the basis for the moral order and shared beliefs, values and activities within the Sufi communities. Hervieu-Léger claims that charismatic authority in the conditions of privatization and individualization of religiosity provides a "base-platform of certainty" for religious community, legitimizing beliefs and practices ${ }^{41}$. Paradoxically, religious individualism that undermines inherited religious traditions and the collective identities based on them facilitates reinventing local identities built around redemptive sociality and charisma.

\footnotetext{
${ }^{38} \mathrm{~J}$. Hazen, Beyond Whirling and Weeping, "Polyvocia - The SOAS Journal of Graduate Research" 2011, No. 3, p. 24.

${ }^{39}$ O. Yarosh, Religious Authority..., p. 191.

${ }^{40}$ A. Bottcher, Sunni and Shi'i networking in the Middle East, [in:] Shaping the current Islamic Reformation, ed. B.A. Robertson, London 2003, p. 49.

${ }^{41}$ D. Hervieu-Léger, op. cit.
} 